\title{
Formation of Readiness of Higher Education Institutions' Students to the Introduction of Musical-Pedagogical Technologies
}

Olga Oleksiuk ${ }^{1}$, Vladimir Cherkasov², Olga Yezhova ${ }^{3}$, Svetlana Kulikova ${ }^{4}$, Snezhana Kurkina ${ }^{5}$, Julia Lokareva ${ }^{6}$

1 Borys Grinchenko University, 18/2 Boulevard-Kudryavska St., Kiev, Ukraine, UA-04053, o.oleksiuk@kubg.edu.ua

2 Volodymyr Vynnychenko Central Ukrainian State Pedagogical University, 1 Shevchenko St., Kropyvnytskyi, Ukraine, UA-25006, cherkasov_2807@ukr.net

3 Volodymyr Vynnychenko Central Ukrainian State Pedagogical University, 1 Shevchenko St., Kropyvnytskyi, Ukraine, UA-25006, oyezhova70@gmail.com

4 Volodymyr Vynnychenko Central Ukrainian State Pedagogical University, 1 Shevchenko St., Kropyvnytskyi, Ukraine, UA-25006, svetlanagrozan@ukr.net

5 Volodymyr Vynnychenko Central Ukrainian State Pedagogical University, 1 Shevchenko St., Kropyvnytskyi, Ukraine, UA-25006, sneghana28@gmail.com

6 Volodymyr Vynnychenko Central Ukrainian State Pedagogical University, 1 Shevchenko St., Kropyvnytskyi, Ukraine, UA-25006, pednauk@gmail.com

\begin{abstract}
The model for the formation of the readiness of pre-service music teachers to the introduction of music-pedagogical technologies is developed, it includes elements: methodological-targeted; content-technological; productive-evaluative. The created model of the use of music-pedagogical technologies in lessons of musical art in secondary schools contains music perception, vocal-choral work, improvisation, playing on musical instruments, and musical-plastic activity.
\end{abstract}

Keywords: musical-pedagogical technologies, music perception, vocal-choral work, improvisation, playing on musical instruments, musical-plastic activity. 


\section{Introduction}

The integration of the musical-pedagogical education of Ukraine into the world educational space makes it possible to create convergent conditions for the introduction of musical-pedagogical technologies by future teachers of musical art, both at the lessons and in the process of extracurricular activity in artistic-aesthetic education of youth. The use of modern musical-pedagogical technologies involves the interaction of the teacher and students in the studying process, the joint simulation of different situations, the solution of creative tasks. In addition, it effectively promotes the creation of an atmosphere of cooperation and interaction between teacher and students, the formation of professional competence and pedagogical mastery of the teacher, the development of creativity, democracy and tolerance of the subjects of the educational process. The teachers of higher pedagogical educational institutions of artistic direction developed the concept of professional-pedagogical and methodical preparation of future teachers; substantiated the theoretical and methodical principles of introduction of music-pedagogical technologies. In this situation, the study of the problem of forming the readiness of university students to the introduction of musical-pedagogical technologies is timely and relevant.

\section{Literature Review}

At the beginning of the XXI century monographic researches of scientists and teachers of higher pedagogical educational institutions of artistic orientation appeared, which substantiated the essence of modern musical-pedagogical technologies and proved their role in the artistic-aesthetic education of youth. Among them: L. Masol (2015), O. Oleksyuk (2015), G. Padalka (2016), O. Rostovskyi (2015) and other scientists who made a significant contribution to the development of the concept of mass artistic-aesthetic education of schoolchildren, continued to develop the best traditions of vocal-choir schools and studied the influence of the perception of music on the consciousness and actions of listeners. In addition, these scientists actively developed and experimentally explored the influences of the playing on musical instruments and improvisation on the development of individual musical abilities of the students, proved the necessity of study the fundamentals of music for further self-development of schoolchildren. The authors of the research (Habibi, Damasio, Ilari, Veiga, Joshi, Leahy, Haldar, Varadarajan, Bhushan, \& Damasio, 2017) concluded that music perception causes macro- and microstructural brain changes in school-aged children. The article by Habowski and Conte (2019) substantiates that musical education can contribute to the global and evolving development of children.

A number of studies are devoted to the application of modern training technologies in the training of specialists of different profiles.

In the article (Bauer, 2013) music educators' technological pedagogical and content knowledge (TPACK) is investigated. The research by Martinez and Llanes (2019) presents 
a critical analysis of the musical methods recognized in the twentieth century in Colombia education. The current status, potential, and challenges of information and communication technologies for music learning are described in the chapter (Bauer, \& Mito, 2017). The purpose of the study (Dorfman, 2016) is to study the current ideas and problems of music teachers in schools with one-to-one technology programs. The scientists (Reese, Bicheler \& Robinson, 2016) summarized the experience of music teachers using iPad services in their case study. In the pilot study the researcher (Chen, 2019) focused on using mobile tablets to compose music by middle-class pupils. The pilot study (Chen, 2019) focused on using mobile tablets to compose music by middle-class pupils. The article by Albert (2019) highlights pedagogical technologies that motivate students to compose music. The study (Mezhennaya, \& Pugachev, 2018) presents the results of the use of interactive learning methods in engineering profile students teaching. The possibilities for how music's perceptions affect the brain have been examined in the review of scientists (Zatorre, Chen, $\&$ Penhune, 2007). The article by Mykhyda, Yezhova, Abramova, Puliak, Cherkasov, and Chystiakova (2019) describes the use of musical folklore in the environmental education of pre-service teachers when creating design projects. The basic tasks and pedagogical principles for the learning of musical-rhythmic movements of preschool children in the process of vocal-choral activity are determined in the study (Maiba, 2019).

The scholars (Koner \& Eros, 2019) argue that music teachers' professional development needs can be influenced by their professional experience, showing that two new topics, including career changes and informal interactions between music educators, are highly effective. American scientist (Kim, 2019) substantiated that collaboration can be successful through the interaction of teachers and students, a tolerant approach to the organization of the learning process, reflective practice of students and teachers with experienced teachers, careful ordering of teaching approaches and participation. Contemporary music teachers from Korea (Shin, 2019) believe that collaborating with teachers has helped students to become highly professional music teachers. Therefore, such teachers can be another important example of successful student learning. At the same time, they focused on reflective learning, on specific ideas and strategies for improving pedagogical skills. The researcher (Drave, 2019) summarized the experience of instrumental music teachers in the process of studying «Art Instruction» in a large urban school district. Various forms of questionnaire have been suggested, which included the participants' answers, facilitator-researcher journal, field notes and structured one-onone interviews. Curriculum development and preparation of educational rubrics were important for such events, as well as the individual musical abilities of the respondents. The participants found such creative activity motivationally valuable for students.

\section{Research Focus}

The aim of the article is the study of the readiness of university students to introduce musical-pedagogical technologies. 


\section{Research Methodology}

\section{General Background}

The study of the problem of formation of readiness of higher education institutions' students to the introduction of musical-pedagogical technologies has been carried out with the help of theoretical and empirical methods. Theoretical methods include: anal$y$ sis of scientific sources on the research problem which made it possible to determine the object, subject, content of the study, to formulate its objectives, to clarify the essence of the key concepts of the study; modeling method - to develop a model for forming students' readiness to the introduction of musical-pedagogical technologies; empirical methods: conversation - a dialogic method in which a teacher, with the help of well-posed questions, prompts students to reproduce previously acquired knowledge; testing is a method that allows revealing the level of knowledge, skills and abilities, abilities and other personality traits; questionnaire-receiving information by means of respondents' written answers to the system of standardized questions; pedagogical experiment - recording, forming, control, for checking the hypothesis of the study; observational methods - direct and indirect pedagogical observation, self-evaluation and evaluation; statistical - methods of mathematical statistics in order to process the statistical data, to prove the statistical reliability of the results of experimental research.

\section{Instrument and Procedures}

The scientific novelty of the results is to develop a model for the formation of the readiness of higher education institutions' students to the introduction of music-pedagogical technologies. An empirical study has been conducted on the basis of Volodymyr Vynnychenko Central Ukrainian State Pedagogical University, Boris Grinchenko Kiev Pedagogical University, Pavlo Tychyna Uman State Pedagogical University, and Kryvy Rih State Pedagogical University. 212 respondents were involved in the experimental groups. There were 192 students in the control groups. Methodological basis of formation of readiness of higher education institutions' students to introduction of musical-pedagogical technologies establish such methods as: methodological-target (purpose, tasks, approaches, principles); content-technological (stages, content, forms, methods, technologies, means, pedagogical conditions); productively-estimated (components, levels, criteria and indicators).

In accordance with the ethics of organizing and conducting the research, the procedure of participation of first and fourth year students and teachers of professional departments in the experiment has been considered and discussed at the meetings of the professional chairs. Discussion procedure was recorded in the minutes at the meetings of the Department of Pedagogy and Management of Education of Volodymyr Vynnychenko Central Ukrainian State Pedagogical University (Minutes № 2 of September 3, 2019), the Department of History and Theory of Pedagogy of Borys Grinchenko Kyiv Pedagogical 
University (Minutes № 3 of September 16, 2019), Department of Pedagogy and Psychology of Child Development of Pavlo Tychyna Uman State Pedagogical University (Minutes № 2 of September 11, 2019), Department of Pedagogy of Kryvyi Rih State Pedagogical University (Minutes № 3 of September 10, 2019). With this approach, respondents agreed to work in control and experimental groups, and the teachers of these educational institutions to work as experiments.

It has been proved, on the basis of the holding stage of the experiment, that the readiness of the students of the universities to introduce the musical-pedagogical technologies will be more effective according to the following pedagogical conditions:

- systematic and continuous motivation to master the value attitude to the introduction of musical-pedagogical technologies;

- updating the content of the discipline «Theory and Methodology of Musical Education» with quasi-professional tasks for acquiring a system of scientific knowledge and competencies;

- stimulation of responsible attitude to mastering the methods of pedagogical action and the optimal combination of interactive approaches and innovative methods to the introduction of musical-pedagogical technologies in the educational process;

- the direction of students' educational and pedagogical practices in introducing musical-pedagogical technologies and conducting experimental work with students of junior and middle classes on the introduction of experimental methods of work with respondents of control and experimental groups.

In the context of the stated problem, it is necessary to find out the essence of the key concepts of the study. In the scientific literature, the term «technology» (from the Greek «techne» - art, craftsmanship, and «logos» - the doctrine, science, etc.) is increasingly being introduced. Domestic scholars offer the use of certain musical-pedagogical technologies for the acquisition of educational material in music art lessons, the main features of which are their focus on the formation of the musical culture of youth; stimulating interests, needs and tastes; mastering of knowledge, skills and abilities in different types of musical activity; enrichment of artistic and aesthetic experience; development of musical and creative qualities of the person.

In the process of experimental research it has been established that the process of perceiving works of musical art takes place in conjunction with other mental processes, namely: thinking, will, language, feeling, perception, imagination, attention (Masol, 2016). A significant role in this process is played by the students' emotional state and their activity and effectiveness during the perception of musical works. In addition, the perception process is influenced by previous knowledge and previous experience in the field of interpretation of works of musical art, as well as the level of development of individual musical abilities (Rostovskyi, 2011).

Awareness of the methodological approaches to identifying stages of acquaintance with a piece of music makes it possible to propose the following sequence of perception 
of musical art's works, namely: presentation of a piece of music; listening to a piece of music; interpretation of the intonation-shaped content of the work; re-listening and discussing at a new, higher level.

Presentation of a musical work. The presentation (from Lat. praesentation - a way of presenting information) is considered to be an interactive information tool that has its own story, script and structure, aimed at convenient perception of information. Presentation of a piece of music involves providing the listener with complete information about the peculiarities of writing, performing and perceiving a piece of music. In the process of presenting a piece of music, there is an interrelation between text, words, video demonstrations, computer animation, music, graphics and fine arts. The main purpose of the presentation is to provide students with complete information about the piece of music in a convenient and interesting way.

Listening to a piece of music is an important stage in the structure of students' familiarization with the works of the school curriculum. Listening involves the perception of works of musical art for expanding and enriching the intonation and auditory supply of students, the formation of personality's musical culture.

When interpreting the musical-figurative content of a work, children have figurative associations that depend on a number of factors, namely: the teacher's attitude to the perception of the musical work; experience in communication with works of musical art; development of emotional-cognitive interests; personality of the listener; age characteristics of children; the level of formation of value orientations; development of creative thinking and speech culture.

Re-listening and discussing at a new, higher level. The technology of re-listening depends on the purpose of the lesson and involves listening to a piece of music both in its entirety and in its individual parts. During the process of re-listening, the teacher may comment on the background of the music. For better memorization of musical material, it may be necessary to re-listen to individual music topics, singing them throughout the class.

Vocal-choral work envisioned the acquisition of vocal and choral music. The central place in vocal-choral work with children was released to a cinematic playback repertoire (Padalka, 2018). Summarizing different approaches to defining the stages of work over the school playback repertoire, we proposed the following sequence: the introductory word of the teacher; illustration of the drama repertoire; haphazard poetic and musical texts; intelligence and melodies; work on expressiveness.

The opening address of the teacher should be concise and short-lived. The purpose of this phase of work is to create the necessary emotional mood that drives students to engage in creative activity. The teacher should pay attention to the names of the composer and author of the literary text, write them on the board and in the notebook, tell the story of the creation of this work.

An illustration of the work of the school song repertoire should be arranged as follows: the first option - the song is performed by the teacher; the second - students listen to 
it on the record (with the help of a phonogram). For a child's conscious perception of a school song the teacher should focus on the following: the performance must be highly artistic, impeccable and appropriate; the song must be fully presented; it is appropriate to establish and stimulate emotional contact with the class during illustration.

Conversation about poetic-musical text aims to identify the means of musical expression through which the artistic content of the work has been revealed. During the conversation, the educational value of the song content and the means of musical expression, through which the composer created a particular musical image, have been clarified. During the conversation, the teacher focuses the students' attention on the connection of the music with the text. Conversation takes relatively little time, prepares students for conscious work on the reproduction of a musical image, is a means of developing a mental culture and a variety of mental processes, such as: feeling, perception, memory, imagination, emotion, attention.

Learning words and melodies is an important component of working on a school repertoire that takes up a large part of the lesson. The effectiveness of this work depends on the pedagogical skills of the teacher and his / her own method of vocal-choral education.

First of all, it is advisable to use music or songbooks to work on the poetic and musical lyrics of the song. It is recommended to learn the words and the melody at the same time, given that the poetic and musical lyrics of the song are one unit. To study the melody is appropriate for the phrases, focusing on the means of musical expression. Children quickly master musical text by using the voice or ear singing method. When playing a melody, the focus is on the purity of the intonation and accurate reproduction of the rhythmic pattern, and when the song is polyphonic - on the sound of the chords. However, you should not forget the correct pronunciation of words, which has a positive effect on sound and allows you to reveal the musical-artistic image. Now it should be remembered that legato is the primary means of sound in the choir.

Working on expressiveness of performance is the final stage of work on the school repertoire. Previous fragmented work is combined to bring you the highest level of artistic-technical abilities. At the same time, the details are being worked out; the pace, climaxes, caesuras and a general dynamic plan of execution are being specified. At this stage, the teacher's attention is focused on the poetic text, which influences the overall interpretation of the intonation-shaped content of the school song.

Musical-theoretical preparation foresaw an assimilation of the elementary theory of music; mastering knowledge of composers and performers; the study of regularities of the development of the artistic art for the interpretation of musical phenomena and facts. The pupils have acquired the basic musical concepts associated with sound-permeability, metro-rhythm and musical-auditory notions. In addition, they became acquainted with the interesting facts of life and creation of famous composers and performers of the past and present; learned to characterize the musical inheritance of outstanding representatives of national cultures. 
Research-experimental work on the formation of the readiness of students in the universities to improvised activity contributed to the development of individual creative capabilities and musical thinking. In improvisation, the preference has been given to intuition and inspiration (Oleksyuk, 2015). The basis of musical improvisation is the stereotypes of musical thinking, acquired during perception, singing, playing musical instruments. Improvisation took place in the process of free variation with constant updating and enrichment of the music.

Musical improvisation is a process that, in addition to inspiration, needs freedom and peace. The facts of students' improvisation before the lesson, without mediocre participation and inspiration of the teacher have been recorded in practice, depending on the state of mental equilibrium or, conversely.

There are three types of musical improvisation in school practice, namely: vocal improvisation, instrumental improvisation, rhythmic improvisation.

Vocal improvisation is considered to be the most common type of improvisation at music lessons. It is related to some experience of vocal-choral work and is to create a melody according to the task or for your own inspiration. An example of vocal improvisation aimed at the development of a positive tune feeling may be completion the teacher's suggested phrase on tonic, or vice versa, on interrogative intonation. Another example would be a musical dialogue between a teacher and a student. Improvising a tune with a text, for example: the teacher sings «questions», the student improvises in the form of «answers» should be one more example.

Instrumental improvisation is characterized by the creation of a musical composition according to the stereotypes of the musical thinking of the individual and the level of mastery of a particular musical instrument.

The process of improvisation is purely individual in nature and depends on many factors, namely: mastering the skills, or vice versa, lack of playing a musical instrument; the level of development of musical-creative abilities of the individual; students' age opportunities; psychological readiness of children for improvisation; the inspiration needed to make music.

Rhythmic improvisation is the most accessible kind of music playing, in the process of which various rhythmic variants are created in the form of rhythmic accompaniment, which helps to develop children's sense of rhythm and promotes the assimilation of different styles and genres of music. The value of rhythmic improvisation of the person's musical development is no less important than the influence of other music-pedagogical technologies and means of the educational process.

The control of the technique of playing musical instruments took place under the following conditions: first, students should know the technical and performing capabilities of each instrument; secondly, the student must be able to illustrate the performance of one or the same phrase on any instrument that is part of an ensemble or orchestra; and thirdly, to clearly understand the end result of the artistic reproduction of musical accompaniment or musical composition. 
Playing musical instruments is a musical-pedagogical technology or activity used in music lessons, which promotes the formation of performing skills, arouses interest in instrumental music, fosters responsibility and collectivism, develops a sense of rhythm and sound, tune, timbre, dynamic, harmonious, polyphonic hearing. Playing musical instruments helps students to master the means of expressiveness, mastering musical-theoretical knowledge.

Musical instruments used in the lessons can be conditionally classified as follows: instruments with a fixed pitch, among which: stringed instruments - domra, psaltery, balalaika, bandura, harp, zither; wind instruments - pipe, flutes, saxophones, clarinets, trios, simons; percussion instruments - metallophones, xylophones; instruments of uncertain height - rattles, drums, tambourines, castanets, triangles, spoons, sticks, bells.

There is no doubt that the teacher must have a thorough knowledge of the method of organizing instrumental music and be able to interest children to play musical instruments. First, he/she needs to know the technical and performance capabilities of each tool. Second, the teacher should be able to illustrate the performance of one or another phrase on any instrument that is part of an ensemble or orchestra. Thirdly, be clearly aware of the end result regarding the artistic reproduction of the musical accompaniment or musical composition (Cherkasov, 2015).

Undoubtedly, the initiative in the organization of collective music comes from the teacher, who must have the technique of working with the instrumental ensemble, to show tolerance and creativity during the rehearsal process.

Creation of musical-plastic compositions with the help of musical-rhythmic hands on the basis of the proposed musical material occurred in two directions: the first - according to specific settings, that is, with the teacher; the second - on the initiative of the students themselves.

Musical-plastic activity provides an opportunity to observe the personal images of children in the process of collective and individual improvisation is a means of development of metro-rhythmic hearing, promotes a deeper disclosure of the intonation-shaped content of a musical work (Cherkasov, 2015).

The use of modern musical-pedagogical technologies involves the interaction of the teacher and students in the learning process, the joint simulation of different situations, the solution of creative tasks.

When listening to the works of A. Vivaldi «Winter» from the cycle «Seasons» and G. Sviridov «Singing Winter, Voicing» from the cantata «Poem in Memory of S. Esenin» and viewing reproductions of paintings by I. Hrabar «Lutnev Blue» and J. Boksha's «Winter» there is a good place to focus on teens' attention to how composers and artists use musical expressiveness and color matching to reveal the image of winter.

In addition, the children listened to F. Schubert's «Ave Maria», K. Debussy's «The Sea», «Symphony No. 6» by P. Tchaikovsky, J. Gershwin's «Porgy and the Bes,» Scherzo in B Minor» and «Nocturne in C Major» by F. Chopin, H. Gluck's «Orpheus and 
Eurydice», «Scherzo («Joke») from Suite No. 2» by J. Bach, I. Shamo’s «Yatran Games», V. Mozart's «Requiem», J. Rossini's «The Barber of Seville», A. Schnittke's «Suite in the old style», R. Shchedrin's «Carmen Suite», L. Beethoven's «Appassionate», «Heroic» and «The Fifth Symphony».

\section{Research Results}

The effectiveness of the quality of forming the readiness of university students to the introduction of musical-pedagogical technologies depends to a large extent on a purposefully designed model of involving students in active activities that covered such components and their elements: methodological-targeted (purpose, tasks, approaches, principles); content-technological (stages, content, forms, methods, technologies, means, pedagogical conditions); productive-evaluative (components, levels, criteria and indicators). The model of use of music-pedagogical technologies in lessons of musical art in secondary schools is presented in Fig. 1.

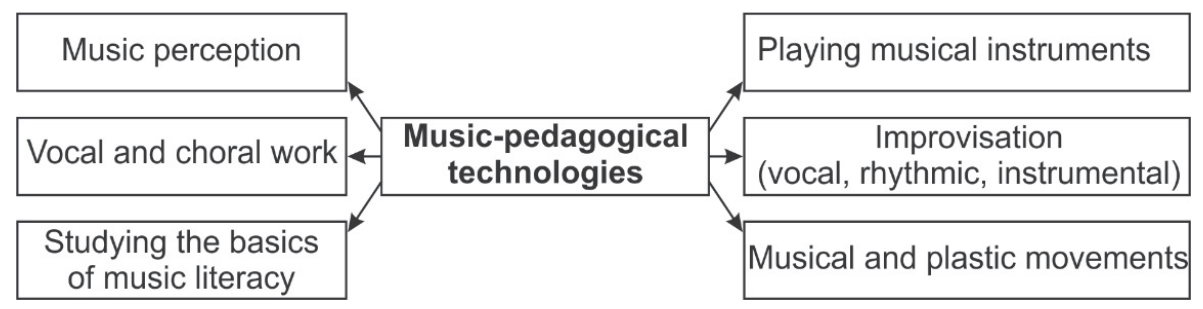

Figure 1. Model of use of music-pedagogical technologies in lessons of musical art in secondary schools

The results of measuring of the students for research before and after the formative experiment are presented in Table 1 and are visualized with a bar chart (Figure 2).

Table 1

Results of measurements of students' readiness for the introduction of musical and pedagogical technologies before and after the formation experiment

\begin{tabular}{lccccccccc}
\hline \multirow{2}{*}{$\begin{array}{c}\text { Readiness } \\
\text { level }\end{array}$} & \multicolumn{3}{c}{ Before experiment } & \multicolumn{3}{c}{ After experiment } \\
\cline { 2 - 11 } & \multicolumn{2}{c}{ CG } & \multicolumn{2}{c}{ EG } & \multicolumn{2}{c}{ CG } & \multicolumn{2}{c}{ EG } \\
\cline { 2 - 10 } & students & $\%$ & students & $\%$ & students & $\%$ & students & $\%$ \\
\hline Low & 54 & 28.3 & 65 & 32.2 & 41 & 21.5 & 30 & 14.9 \\
\hline Medium & 92 & 48.2 & 94 & 46.5 & 99 & 51.8 & 96 & 47.5 \\
\hline High & 45 & 23.6 & 43 & 21.3 & 51 & 26.7 & 76 & 37.6 \\
\hline Total & 191 & 100 & 202 & 100 & 191 & 100 & 202 & 100 \\
\hline$\chi^{2}$ & \multicolumn{7}{c}{0.78} \\
\hline
\end{tabular}




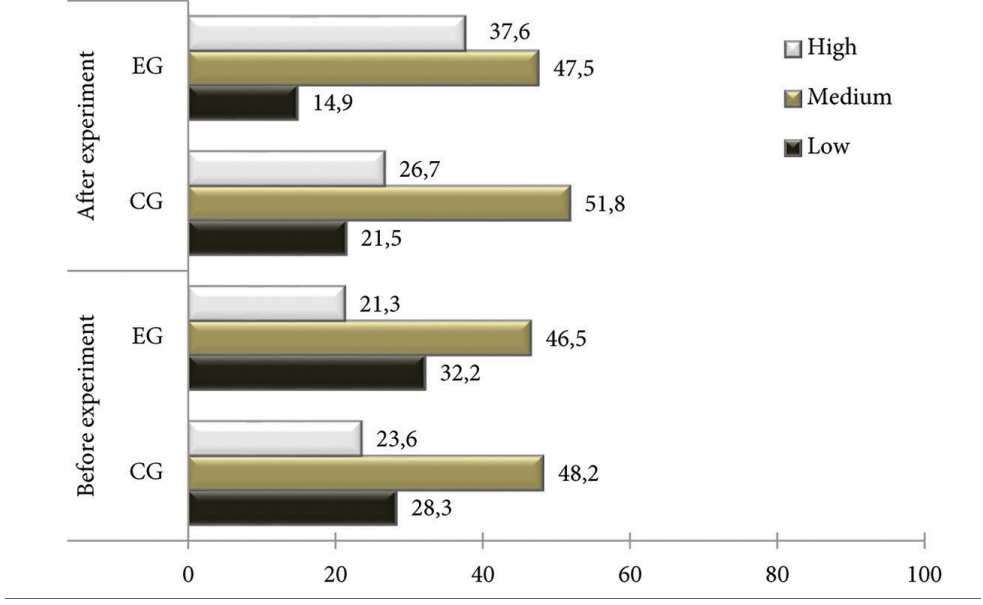

Figure 2. Levels of students' readiness according to the formative experiment findings

\section{Discussion}

On the basis of the analysis of the results of the conducted research, optimization of the quality of formation of readiness of students of higher education institutions to the introduction of musical-pedagogical technologies, obtained by means of theoretical and empirical methods of scientific research data it has been found that:

1. The generalization of the data of the conducted research allowed us to deduce the percentage ratio of levels of formation of readiness of students of the experimental group to the introduction of music-pedagogical technologies: the high level-23.1\%; the average level - 50.5\%; the lowest level - 26.3\%; the control, respectively, $-24.5 \%, 51.6 \%, 24.0 \%$.

2. As a result of experimental work in the control group, the high level of formation of students' readiness to introduction of music-pedagogical technologies has increased in comparison with the reporting stage by $5.2 \%$, the average has decreased by $2.6 \%$, the lowest has decreased by $2.6 \%$. In the experimental group, the high level increased by $17,8 \%$, the average level decreased by $5.9 \%$, the low level decreased by $11.8 \%$.

3. In general, the difference between the high level of readiness of the control and experimental groups' students according to the results of research-experimental work was $11.2 \%$; on average level $-4.6 \%$; on low level $-6.9 \%$.

4. Comparison of the results of 2019 with experimental data obtained in 2014 with students studying under the old programs who did not take into account the method of readiness for the introduction of music and pedagogical technologies in the practice of working with primary school students has shown a positive dynamic. It should be noted that preference for choral singing was given $(2014-15.6 \%, 2019-38.1 \%)$, perception of music $(2014-20.5 \%, 2019$ - 31.9\%), games on musical instruments (2014 -14.7\%, 2019 - 
23.1\%), improvisation (2014 - 18.3\%, 2019 - 25.4\%), musical-plastic activities (2014 - 17.8\%, $2019-25.6 \%)$, the study of the basics of musical literacy (2014 - 13.2\%, $2019-21.8 \%$ ), which testifies to the effectiveness of the proposed methodology.

5. Thus, the readiness of future students to introduce music-pedagogical technologies in music lessons in primary school in KG is: Nk $0=3.06$ (61.2\%), EG - No $0=4.05$ (81.0\%). The difference is significant, amounting to $19.8 \%$ and is taken into account in the subsequent calculations.

The results of the study indicate that before the organization of research- experimental work, students of experimental and control groups were at about the same level of readiness, but after the experimental work the experimental group students showed higher results, and we can conclude that when organizing a targeted process of forming the readiness of university students to the introduction of musical-pedagogical technologies, their level has significantly increased.

\section{Conclusions and Implications}

We carried out a diagnosis of the formation of readiness of higher education institutions' students to the introduction of musical-pedagogical technologies, which included monitoring the process of its formation and the forming experiment itself. The results of the monitoring of the contents of disciplines in the cycle of general and professional training showed that the structure of most of them reveals the theoretical and practical issues of readiness of students of higher education to the introduction of musical-pedagogical technologies. The pedagogical conditions, offered by us, contributed to the formation of readiness of university students to the introduction of musical-pedagogical technologies. The conducted study does not exhaust all aspects of the problem of forming the readiness of university students to the introduction of musical-pedagogical technologies. A promising direction may be a comparative study of international experience of forming the readiness of university students to the introduction of musical-pedagogical technologies.

\section{References}

Albert, D. J. (2019). The Classroom Culture of a Middle School Music Technology Class. International Journal of Music Education, 0255761419881483. doi: 10.1177/0255761419881483 Bauer, W. (2013). The Acquisition of Musical Technological Pedagogical and Content Knowledge. Journal of Music Teacher Education, 22(2), 51-64. doi: 10.1177/1057083712457881

Bauer, W. I., \& Mito, H. (2017). ICT in Music Education. In The Routledge Companion to Music, Technology, and Education, (pp. 115-126). Routledge. 
Chen, J. C. W. (2019). Mobile Composing: Professional Practices and Impact on Students' Motivation in Popular Music. International Journal of Music Education. doi: 10.1177/0255761419855820

Cherkasov, V. F. (2015). Theory and Methods of Music Education. Kirovograd: KSPU V. Vinnichenko.

Dorfman, J. (2016). Music Teachers' Experiences in One-to-one Computing Environments. Journal of Research in Music Education, 64(2), 159-178. doi: 10.1177/0022429416649947

Draves, T. J. (2017). Instrumental Music Educators' Experiences in a Professional Development Course. Update: Applications of Research in Music Education, 35(3), 38-45. doi: 10.1177/8755123316634174

Habibi, A., Damasio, A., Ilari, B., Veiga, R., Joshi, A. A., Leahy, R. M., Haldar, J. P., Varadarajan, D., Bhushan, C., \& Damasio, H. (2017). Childhood Music Training Induces Change in Micro and Macroscopic Brain Structure: Results from a Longitudinal Study. Cerebral Cortex, 28(12), 4336-4347. doi: 10.1093/cercor/bhx28

Habowski, A. C., \& Conte, E. (2019). Music in Child Education: (Re) Discovering Senses. Revista Praxis Educacional, 15 (35), 444-469. doi: 10.22481/praxisedu.v15i35.5691

Kim, J. (2019). Implementing a Co-Teaching Model in Music Student Teaching: A Literature Review. Update: Applications of Research in Music Education, 38 (1), 18-24. doi: 10.1177/8755123319843169

Koner, K., \& Eros, J. (2019). Professional Development for the Experienced Music Educator: A Review of Recent Literature. Update: Applications of Research in Music Education, 37(3), 12-19. doi: $10.1177 / 8755123318812426$

Kulikona, S.V. (2017). The Essence and Structure of Professional Competence of Future Teachers of Musical Art. Scientific notes of the KSPU. Series: Pedagogical Sciences, 157, 156-159.

Kurkina, S.V. (2018). Musical-aesthetic Education of Children of Adolescence and Youth in the Practice of Institutions of Extra-curricular Artistic Education. Scientific notes of the KSPU. Series: Pedagogical Sciences, 170, 84-89.

Lokareva, Yu.V. (2017). Pedagogical Conditions of Professional Formation of Future Teachers of Musical Art. Scientific notes of the KSPU. Series: Pedagogical Sciences, 150, 155-159.

Maiba, O. (2019). The Role of Musical-rhythmic Movements of Children of Pre-school Age in the Process of Vocal-choral Activity. Journal of History Culture and Art Research, 8(3), 285-292. doi: 10.7596/taksad.v8i3.2040

Masol, L. M. (2016). General Artistic Education: Theory and Practice: Monograph. Kiev: Projn.

Martinez, M. D., \& Llanes, B. C. M. (2019). An Integrative Method of Musical Education for the Secondary School. Revista universidad y sociedad, 11 (5), 349-355.

Mezhennaya, N. M., \& Pugachev, O. V. (2018). On the Results of Using Interactive Education Methods in Teaching Probability Theory. Problems of Education in the 21st Century, 76(5). Retrieved from http://oaji.net/articles/2017/457-1540320285.pdf

Mykhyda, S. P., Yezhova, O. V., Abramova, O. V., Puliak, O. V., Cherkasov, V. F., \& Chystiakova, L. O. (2019). Environmental Education of Young People in Carrying out Design Projects on the Basis of Literary and Musical Folklore. Romanian Journal for Multidimensional 
Education / Revista Romaneasca pentru Educatie Multidimensionala, 11(4), 175-192, doi: $10.18662 / \mathrm{rrem} / 165$

Oleksyuk, O. M. (2015). Musical Pedagogy. Kiev: KNUKiM.

Padalka, G. M. (2018). Pedagogy of Art (theory and methodology of teaching artistic disciplines).

Kiev.

Reese, J. A., Bicheler, R., \& Robinson, C. (2016). Field Experiences using iPads: Impact of Experience on Preservice Teachers' Beliefs. Journal of Music Teacher Education, 26(1), 96-111. doi: 10.1177/1057083715616441

Rostovsky, O. Ya. (2011). Theory and Methodology of Musical Education: Teaching Method. Ternopil.

Shin, J. (2019) Becoming a Music Teacher: Korean Music Student Teachers' Perceptions of Their Student Teaching Experience. Music Education Research, 21(5), 549-559, doi: 10.1080/14613808.2019

Zatorre, R. J., Chen, J. L., \& Penhune, V. B. (2007). When the Brain Plays Music: Auditory-Motor Interactions in Music Perception and Production. Nature reviews neuroscience, 8(7), 547-558. doi:10.1038/nrn2152

\section{Aukštujų mokyklų studentų pasirengimas muzikinèms- pedagoginèms technologijoms diegti}

\section{Olga Oleksiuk ${ }^{1}$, Vladimir Cherkasov ${ }^{2}$, Olga Yezhova $^{3}$, Svetlana Kulikova ${ }^{4}$, Snezhana Kurkina ${ }^{5}$, Julia Lokareva ${ }^{6}$}

1 Boriso Grinčenkos universitetas, Boulevard-Kudryavska g. 18/2, Kijevas, Ukraina, UA- 04053, o.oleksiuk@kubg. edu.ua

2 Vladimiro Viničenko Centrinès Ukrainos valstybinis pedagoginis universitetas, Ševčenkos g. 1, Kropyvnytskyi, Ukraina, UA-25006, cherkasov_2807@ukr.net

3 Vladimiro Viničenko Centrinès Ukrainos valstybinis pedagoginis universitetas, Ševčenkos g. 1, Kropyvnytskyi, Ukraina, UA-25006, oyezhova70@gmail.com

4 Vladimiro Viničenko Centrinès Ukrainos valstybinis pedagoginis universitetas, Ševčenkos g. 1, Kropyvnytskyi, Ukraina, UA-25006, svetlanagrozan@ukr.net

5 Vladimiro Viničenko Centrinès Ukrainos valstybinis pedagoginis universitetas, Ševčenkos g. 1, Kropyvnytskyi, Ukraina, UA-25006, sneghana28@gmail.com

6 Vladimiro Viničenko Centrinès Ukrainos valstybinis pedagoginis universitetas, Ševčenkos g. 1, Kropyvnytskyi, Ukraina,UA-25006, pednauk@gmail.com

\section{Santrauka}

Šis tyrimas, aukštųjų mokyklų studentų pasirengimas diegti muzikines-pedagogines technologijas, atliepia šių dienų laikotarpị. Mokslinis rezultatų naujumas - plètoti aukštųjų mokyklų studentų pasirengimo modelị diegiant muzikines-pedagogines technologijas. Sukurtas 
muzikinių-pedagoginių technologijų panaudojimo modelis apima muzikos suvokimą, vokalinịchorinị darbą, muzikinès literatūros studijavimą, improvizaciją, grojimą muzikos instrumentais ir muzikinę-plastinę veiklą. Tyrimas atliktas Centrinès Ukrainos regione, aukštojo mokslo istaigose. Eksperimentinèse grupėse dalyvavo 212 respondentų, kontrolinėse grupèse - 192 respondentai. Praktinė šių rezultatų reikšmė yra ta, kad studentai skatinami toliau dirbti šio tyrimo kryptimi ir kad tai yra neabejotinas indèlis plètojant muzikinio-pedagoginio ugdymo teoriją ir metodiką.

Apibendrinti atlikto tyrimo duomenys leido nustatyti eksperimentinès grupès studentu pasirengimo muzikos pedagoginėms technologijoms diegti procentinị lygio santykį: aukščiausias lygis - 23,1 proc.; vidutinis lygis - 50,5 proc.; žemiausias lygis - 26,3 proc.; taip pat atitinkamai kontrolinès grupés - 24,5 proc., 51,6 proc., 24,0 proc.

Tyrimo rezultatai rodo, kad, prieš pradedant organizuoti tiriamąjit-eksperimentinị darbą, eksperimentinių ir kontrolinių grupių studentai buvo maždaug to paties pasirengimo lygio, tačiau atlikę eksperimentinị darbą eksperimentinès grupès studentai pasiekè aukštesnių rezultatų. Vadinasi, galime daryti išvadą, kad organizuojamas tikslingas aukštųjų mokyklų studentų, būsimų muzikos mokytojų, pasirengimas diegti muzikines-pedagogines technologijas gerokai pakèlè studentų lygí.

Esminiai žodžiai: muzikinès-pedagoginès technologijos, muzikos suvokimas, vokalinis-chorinis darbas, improvizacija, grojimas muzikos instrumentais, muzikine-plastinè veikla. 